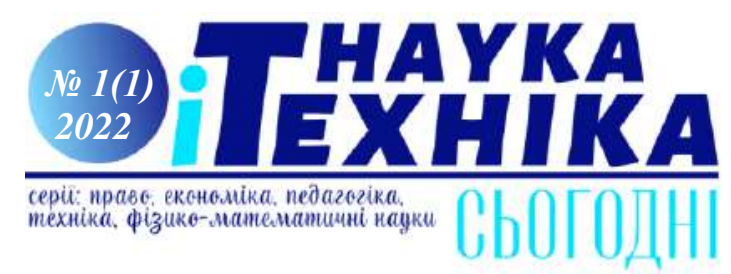

УДК 35

https://doi.org/10.52058/2786-6025-2022-1(1)-137-143

Залізнюк Вікторія Петрівна доктор наук 3 державного управління, професор кафедри світової економіки Київського національного торговельноекономічного університету, вул. Кіото, 19, м. Київ, 02000, тел.: (067) 407-79-97, https://orcid.org/0000-0002-7014-0207

\title{
ХАРАКТЕРИСТИКА УПРАВЛІННЯ ЕКОНОМІЧНОЮ ПОВЕДІНКОЮ ПІДПРИЧСТВ НА ТЕРЕНАХ ЄВРОПЕЙСЬКОГО СОЮЗУ
}

Анотація. Мета статті - дослідити аспекти управління економічною поведінкою підприємств на прикладі країн Свропейського Союзу. Виявлено, що сталість та амортизаційні властивості економіки країн Свропи залежать, в тому числі, від успішності та фінансової ефективності малого та середнього бізнесу. Підприємництво, водночас, має характер транснаціонального світового здобутку : так, для більшості країн-членів Європейського Союзу свобода підприємництва та торгівлі ототожнюється із природним правом, закладених у Основних законах вищезазначених держав.

Відмічено, що у контексті інтенсифікованого, ефективного та економічно обгрунтованого контролю за економічною діяльністю підприємств Свропейським Союзом обирається концепт фінансового планування. Обгрунтування колообігу фінансових активів комерційних установ, регламентація фінансових правовідносин між державно-владним апаратом та сектором підприємництва формують сутнісно-амортизаційну характеристику управління економічною поведінкою підприємств на теренах Європейського Союзу. Водночас, інтенсифікований контроль за діяльністю підприємств та їх економічним потенціалом дозволяє забезпечити актуально-оптимальні передумови для дієвого господарського обороту, та, зокрема, досягнення фінансової прибутковості підприємницької діяльності. Відтак, одним із основним завдань країн-членів Європейського Союзу $є$ забезпечення підприємницького сектору економіки належним об'ємом коштів, які матимуть гіпотетичну можливість до трансформації у оборотні та необоротні комерційні активи.

Доведено, що економіко-політичний устрій Європейського Союзу має уніфіковану, індивідуалізовану управлінську структуру. У цьому контексті особливо важливим є пошук засобів покращення ефективності управління економічною поведінкою підприємств.

Обгрунтовано роль та місце фінансового планування у побудові багаторівневого та індивідуалізованого контрольно-ревізійного механізму 
управління економічною поведінкою підприємств, 3 огляду на досвід країнчленів Європейського Союзу.

Ключові слова : державна політика, економічна поведінка, фінансове планування, контрольно-ревізійний механізм, країни-члени Свропейського Союзу.

Zalizniuk Victoria Petrovna Doctor of Science in Public Administration, Professor of the Department of World Economy, Kyiv National University of Trade and Economics, str. Kyoto, 19, Kyiv, 02000, tel : (067) 407-79-97, https://orcid.org/0000-0002-7014-0207

\section{CHARACTERISTICS OF MANAGEMENT OF ECONOMIC BEHAVIOR OF ENTERPRISES IN THE EUROPEAN UNION}

Abstract. The purpose of the article is to explore aspects of managing the economic behavior of enterprises on the example of the European Union. It was found that the sustainability and depreciation properties of European economies depend, inter alia, on the success and financial efficiency of small and medium-sized businesses. Entrepreneurship, at the same time, has the character of a transnational world achievement: for example, for most member states of the European Union, freedom of enterprise and trade is identified with the natural law enshrined in the Basic Laws of the above-mentioned states.

It is noted that in the context of intensified, effective and economically sound control over the economic activity of enterprises, the European Union chooses the concept of financial planning. Substantiation of the cycle of financial assets of commercial institutions, regulation of financial relations between the state apparatus and the business sector form the essence and depreciation characteristics of the management of economic behavior of enterprises in the European Union. At the same time, intensified control over the activities of enterprises and their economic potential allows to provide relevant and optimal conditions for effective economic turnover, and, in particular, to achieve financial profitability of entrepreneurial activity. Therefore, one of the main tasks of the member states of the European Union is to provide the business sector of the economy with an adequate amount of funds that will have a hypothetical opportunity to transform into current and non-current commercial assets.

It is proved that the economic and political system of the European Union has a unified, individualized management structure. In this context, it is especially important to find ways to improve the management of economic behavior of enterprises.

The role and place of financial planning in the construction of a multilevel and individualized control and audit mechanism for managing the economic behavior of enterprises, based on the experience of European Union member states, is substantiated. 


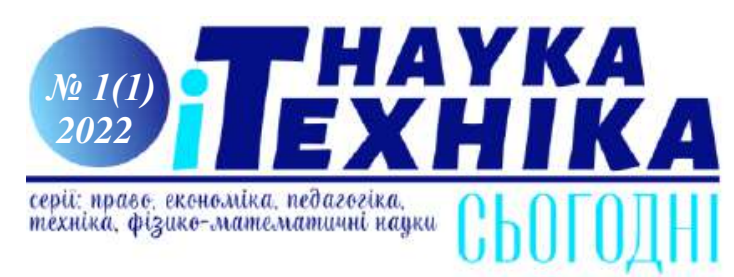

Keywords: state policy, economic behavior, financial planning, control and audit mechanism, member states of the European Union.

Постановка проблеми. В сучасних умовах, успішність підприємництва та бізнесу виступають показником загальнодержавного політико-соціального потенціалу, відображаючи вірність обрання країнами-членами Європейського Союзу державно-управлінського курсу. Однак, саме управління та ревізійна діяльність, що полягає у інтенсифікованому контролі за діяльністю підприємств, створює об’єктивно законну, виходячи із досвіду Європи, модель комерціалізованої торгівлі. Підприємництво є засобом реалізації приватних та державних економічних завдань, сприяє збагаченню державного потенціалу, забезпечує ієрархічну побудову вмотивованих фінансових правовідносин із представниками урядування, бізнес-партнерствами та кредитно-економічними підрозділами Європейського Союзу. Необхідно зауважити, що додатковим чинником, що зумовлює необхідність процесу глобалізації економічного контролю за підприємницьким сектором в Свропейському Союзі, є координація відносин глобалізованого інформаційного партнерства з іншими державами.

Аналіз останніх досліджень і публікацій. Проактивність економічного потенціалу Свропейського Союзу на рівні міжнародно-правового економічного співробітництва зумовлює необхідність комплексного опрацювання організаційно-управлінських основ інтенсифікованого управління економічною поведінкою підприємств із урахуванням досвіду країн-членів Європейського Союзу. Отже, особливої нагальності набуває дослідження управління економічною поведінкою підприємств на території Свропи. Варто виокремити наукові здобутки Терещенко О.О., Панкова В.А., Ляшенко Г.П., Ковальова В.В., Данилюка М.О., Блокманса В. та інших.

Мета статті - визначити концептуальні аспекти інтенстифікованого управління поведінкою підприємств, опираючись на досвід країн-членів Європейського Союзу.

Виклад основного матеріалу. 3 позицій економічних та фінансових теорій, бюджетування підприємств є основним фактором, що визначає та спрямовує діяльність підприємств. Через це, для Європейського Союзу, у хронологічно-зворотній перспективі, основним завданням завжди було нормувати, систематизувати та уніфікувати контрольно-наглядову державноуправлінську систему.

Одночасно, Європейська політика регіонального розвитку, котра покликана забезпечити рівність усіх держав-учасниць Союзу за Маастрихтським договором, визначає необхідність розробки політики підтримки : так, враховуються виробничі, комерційні та дохідні обсяги фінансових активів підприємств, проводиться галузевий компаративний аналіз фінансово-економічної доцільності за країнами, регіонами та адміністративнотериторіальними одиницями країн-членів Свропейського Союзу [1]. 

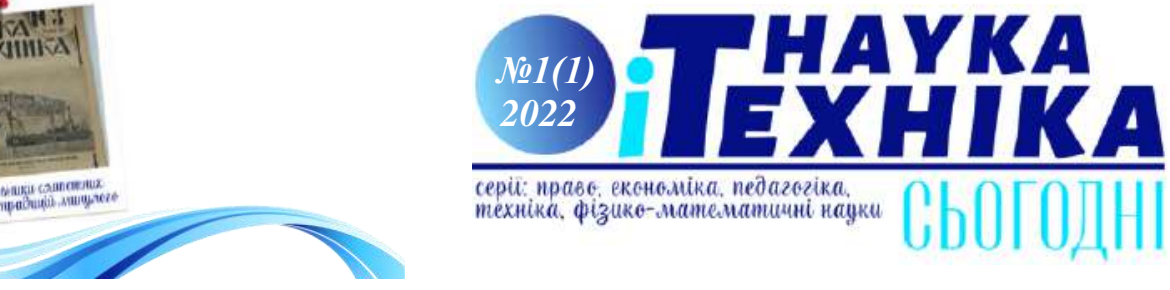

серіи: праве, ексноміка, педагогіка, техніка, фізико-манемаминиі науки

Загалом, саме міжурядовий, локально-муніципальний розвиток суспільнодержавних процесів у Європі зумовлює посилений контроль за економічною діяльністю країн-членів Свропейського Союзу.

Наприклад, у Великобританії проведення планових перевірок бізнесу ініціюється Палатою Представників : вони відбуваються у формі ревізій, переглядів економічно-впорядкувальної документації, співставлення операційного фактажу підприємництва, задекларованих доходів та витрат. Дещо архаїчний підхід Британії, однак, відзначається високим рівнем ефективності : виробничі процеси прозорі, а економічний потенціал держави $\epsilon$ загальновизнаним.

В той же час, Бундесрат та Бундестаг (Німеччина та Австрія), виступаючи за чесний, прозорий та легальний бізнес, реалізують наступні державно-курсові постулати : заохочення та культивація малого бізнесу, його підтримка - i, як підсумок, розвиток ніші середнього бізнесу; гарантії для підприємств, їх управлінців та працівників - у розрізі забезпечення робочим капіталом, ринком споживчих послуг та ініціаторства затвердження окремих товарних сегментів для збуту на території Європейського Союзу. Фактично, в даному випадку контрольно-ревізійний аспект впливу на економічну прозорість підприємств носить радше імперативно-диспозитивний, аніж суто імперативний характер [2].

Вважаю за необхідне сконцентрувати увагу на партикулярності щодо контексту стандартизації інтенсифікації управління економічною діяльністю підприємств у Люксембурзі. Так, середній дохід ВВП на душу населення тут найвищий у Свропі. Обгрунтовується це, першочергово, розвиненою сферою послуг, в тому числі - у галузі підприємництва [3].

Задля збереження конкретизованого та ієрархічно впорядкованого державноуправлінського підходу, урядом Люксембургу було сформовано апарат контролю за підприємницькою діяльністю : його специфікою $є$ наявність системи спрощеної фінансової звітності, що реалізується шляхом непрямої процедури оподаткування - зокрема, корпоративного податку на дохід підприємництва та муніципально-комерційного оподаткування. Також, активного розвитку набув громадський контроль - ефективність та дохідність корпоративних бізнесорганізацій Люксембургу коорлинується не лише за допомогою законопроєктів, але й предметного втілення прямих форм демократії [4].

В той же час, важливої ролі у процесі активного управління економічною діяльністю підприємств на території Свропейського Союзу набув процес фінансового планування. За базовим визначенням, основоположним принципом комерційно-підприємницького планування виступає методика балансу. Нею, зокрема, передбачено раціональні, економічні та фінансово обгрунтовані ресурсні витрати, які схвалюються ревізійними радами країн Свропи лише за умови фінансово-пропорційної необхідності у регламентації оборотних та необоротних активів підприємств. 
У дійсності, процес економічно обгрунтованих витрат підприємств ототожнюється із загальним рівнем економічної інтегративності країн-членів Свропейського Союзу. Рівень інтенсифікації управління економічною поведінкою підприємств обумовлюється наступними реальними фінансово-ресурними лімітуваннями, характеристикою реального планування та універсалізму затверджених планових підприємницько-комерційних розрахунків [5].

На Рис. 1 представлено систематизовану структуру інтенсифікованого управління економічною поведінкою підприємств за прикладом країн-членів Європейського Союзу.

\section{Уряд}

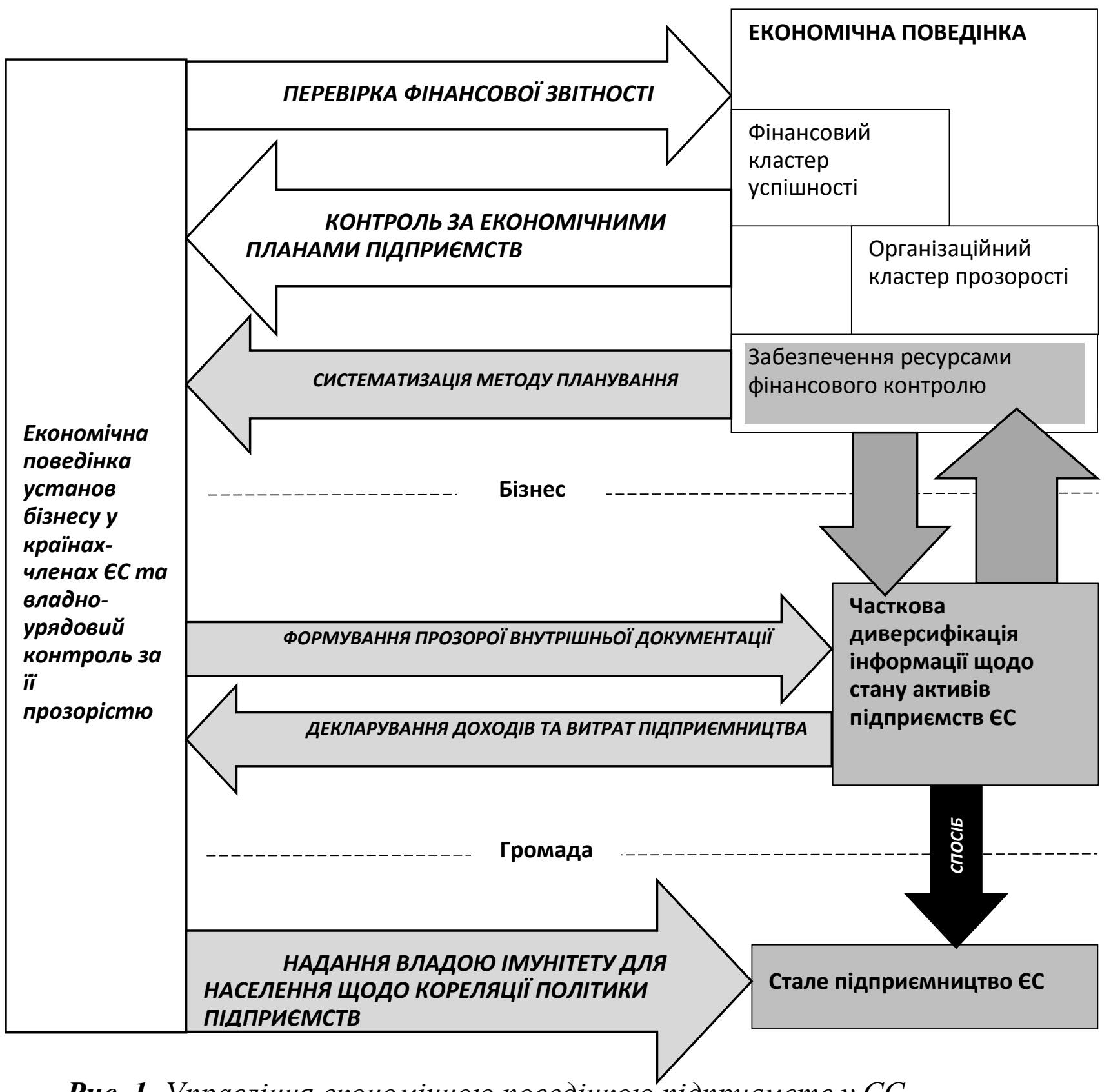

Pис. 1. Управління економічною поведінкою підприємств у ЄС 


\section{(1)}

Важливо зазначити, що управління економічною поведінкою підприємств на теренах Європейського Союзу має тенденцію до правової та управлінської рецепції. Так, у Швейцарії, подібно Люксембургу, застосовуються методики управління загальнонаціональним капіталом посередництвом контролю за діяльністю підприємств. Аналогічно, застосування економіко-математичних моделей комерціалізованого управління допомагає культивувати більш прозоре та активно розгалужене використання фінансової звітності у якості антикорупційного інструмента $[6 ; 7 ; 8 ; 9 ; 10]$.

По факту, дієве, гласне, політично незалежне управління економічною діяльністю підприємств, з огляду на досвід Європи, забезпечується аналітикооперативною діяльністю процесу фінансового аналізу комерційних підприємств. Деталізоване опрацювання отриманих макро- та мікроекономічних показників за окремий період дозволяє співставляти індексні значення реальних та фактично задекларованих показників, таким чином попереджуючи прояви монополізації ринків товарів та послуг окремими суб’єктами підприємництва країн-членів Свропейського Союзу.

В свою чергу, фінансування бізнесу на рівні Європейського Союзу здійснюється за інноваційною кривою, що дозволяє трансформувати процедуру інвестування в бізнес у більш технологічну площину. До прикладу, Європейський парламент продовжує визначати інфраструктуру засадничою ланкою економічного добробуту підприємств, водночас наголошуючи на обов'язковому контролі щодо їх діяльності. Управління економічною поведінкою підприємств у Європейському Союзі, відтак, має однорідну, логічну структуру.

Висновки. Інтенсифіковане управління економічною поведінкою підприємств на теренах Європейського Союзу є логічно впорядкованим, структуризованим державно-управлінським механізмом. Уряд та населення формують єдину контрольно-ревізійну систему, що дозволяє оперативно відстежувати порушення податкового та економічного законодавства підприємствами. Отже, комерційна складова підприємництва у Європейському Союзі широко розвивається, координуючись та спрямовуючись органами влади, в тому числі - Свропейським парламентом.

\section{Jimepamypa:}

1. Панков В.А. Контроллінг та бюджетування діяльності підприємства // Навчальнометодичний посібник // В. А. Панков, С. Я. Слецьких, Н. М. Михайличенко . - Краматорськ, 2006. - 128 c.

2. Данилюк М.О., Лещій В. П. Теорія і практика процесно-орієнтованого управління витратами : наук. Видання - Івано-Франківськ : $2002 .-248$ с.

3. Ковальов В.В. Фінансовий менеджмент : теорія і практика .-2-е вид, перероблене та доповнене // В.В. Ковальов .- Москва : вид-во Проспект, 2007. - 412 с.

4. Blockmans W. Civil Rights and Political Participation in Ancien Regime Europe // Вісник Санкт-Петербурзького ун-ту, Історія 2020 // Т.65, вип. 3., с. 842-864 
